\title{
VISUAL ACUITY IN MYOPES WITH STANDARD AND REVERSED CONTRAST OPTOTYPES
}

\author{
Gatis Ikaunieks", Anete Petrova, Karola Panke, and Gunta Krūmiṇa \\ Department of Optometry and Vision Science, University of Latvia, Jelgavas iela 1, Riga, LV-1004, LATVIA \\ gatis.ikaunieks@lu.Iv; anete.petrova@lu.Iv; karola.panke@inbox.lv; gunta.krumina@lu.lv \\ \# Corresponding author
}

Communicated by Ivars Lācis

\begin{abstract}
The aim of this study was to assess the visual acuity of myopes with standard and reversed contrast optotypes and to determine how the visual acuity of myopes is affected by optical defocus and the type of optical correction, either contact lenses or spectacles. Twenty-three myopic subjects (18 and 23 years old) with uncorrected vision had their visual acuity assessed with both standard and reversed contrast optotypes. The study also included 10 myopes with contact lens as well as habitual spectacle correction. The visual acuity for myopes with uncorrected vision was better with reversed than standard contrast optotypes. Better reversed contrast than standard contrast visual acuity was obtained also with spectacle and contact lens correction. This result could be due in part to low order aberrations (optical defocus) in myopes spectacle or contact lenses correction.
\end{abstract}

Key words: myopia, visual acuity, contrast, optical correction, optical defocus.

\section{INTRODUCTION}

Visual acuity is one of the primary measures of visual function in clinical settings. It can be affected by many factors, one of which is contrast polarity of optotypes. Usually, visual acuity is tested with dark symbols on a bright background (called standard or negative Weber contrast). Sometimes also bright symbols on a dark background are used (reversed or positive Weber contrast). For young adults without any eye pathologies and with normal or correctedto-normal visual acuity, the difference between visual acuity on standard and reversed contrast optotypes is the same or better when viewing standard contrast stimuli (Westheimer et al., 2003; Piepenbrock et al., 2013). Better visual acuity when viewing reversed contrast stimuli (as opposed to standard contrast stimuli) can be due to two main factors - increased eye optical aberrations (Marcos et al., 2008) and light scattering in the eye (Miyajima, 1992; Westheimer et al., 2003). Only a small number of studies have investigated the impact of ocular aberrations on standard and reversed contrast visual acuity. Westheimer (Westheimer, 2003) theoretically explained the effect of aberrations on visual acuity values associated with both contrast polarities. Marcos et al. showed that both reversed and standard contrast visual acuity ratios decrease when eye aberrations are corrected with adaptive optics (Marcos et al., 2008).

There are a greater number of studies (Rubin and Legge, 1989; Miyajima, 1992; Westheimer, 2003; Westheimer et al., 2003 ) in which the impact of light scattering in the eye (retinal straylight) on recognition of different contrast polarity stimuli has been assessed. As mentioned previously, light scattering affects standard visual acuity to a greater extent than reversed contrast visual acuity (Miyajima, 1992; Westheimer et al., 2003). Retinal straylight increases with age (Whitaker and Elliott, 1992); therefore, it is expected that visual acuity of older persons is better when viewing reversed rather than standard contrast optotypes. Westheimer et al. (2003) research confirmed this expectation, but Piepenbrock et al. (2013) showed that for both younger and older persons, visual acuity is better when viewing standard contrast, rather than reversed contrast stimuli. Such contradictory results might be related with different lighting conditions in the studies.

Some results from other authors' researches indicate that better visual acuity with reversed rather than standard contract optotypes also occurs in young myopes with the best corrected visual acuity. Stoimenova (2007) showed that myopes with corrected vision exhibit a lower (better) contrast threshold when viewing reversed rather than standard Weber contrast optotypes. This was attributed to eye aberrations and to changes in retinal morphology due to myopia (Stoimenova, 2007). Contrast sensitivity is related to visual acuity (Haegerstrom-Portnoy et al., 2000) and therefore we may expect to see that also visual acuity for myopes improves when viewing reversed contrast stimuli. Additional factors, which in some cases can increase retinal straylight 
and therefore reduce standard contrast visual acuity for myopes, are longer axial length of myopes eye compared to emmetropes (Rozema et al., 2010) and light scattering created by spectacles (de Wit and Coppens, 2003) and contact lenses (Elliott et al., 1991; Miyajima, 1992; Cervińo et al., 2008; van der Meulen et al., 2010).

Usually clean spectacles (de Wit and Coppens, 2003) and soft contact lenses (Cervińo et al., 2008; van der Meulen et al., 2010) do not significantly increase retinal straylight. However, Allen et al. (2008) showed that contact lens wearers observe a larger halo around light sources compared to spectacle wearers. Our main interest was to evaluate the changes in visual acuity for myopes depending on the contrast we used for optotypes (standard or reversed) and to see whether the results were affected by the type of optical correction (contact lenses or spectacles). Also, we assessed the impact of low order aberrations (optical defocus) on visual acuity results, as only influence of higher order aberrations on standard and reversed visual acuity has previously been showed (Marcos et al., 2008).

\section{MATERIALS AND METHODS}

Thirty-nine young adults free of ocular diseases (age between 18 and 23 years) participated in this study. Twentythree of them were myopes with subjective refraction between -0.5 to $-6.00 \mathrm{D}$, astigmatism $\leq 1.00 \mathrm{D}$. 16 emmetropes within the same age group served as control subjects.

Unaided visual acuity was tested for all subjects with standard and reversed contrast optotypes. Visual acuity measurements with both contrast stimuli were taken in random order for all participants.

Ten of the subjects from the myope group with habitual visual acuity 1.0 or more (decimal units) were tested with their spectacles or contact lenses. Their spherical refractive errors ranged between -1.75 to $-6.00 \mathrm{D}$, astigmatism $\leq 1.00 \mathrm{D}$. The interval between measurements with and without optical correction was from 1hour till one day. None of the subjects had eyeglasses older than three years, and there were no clearly visible scratches on the lens surfaces. All spectacle lenses were made of plastic material and were covered with an anti-reflection coating. Lenses were cleaned with a clean microfiber cloth before testing. These same 10 myopes underwent visual acuity testing while wearing new daily or monthly soft silicone hydrogel contact lenses. The interval between measurements done with spectacles and contact lenses was at least 1 hour. The corrected vision spherical refractive errors (in contact lenses) were between $-1.75 \mathrm{D}$ and $-5.75 \mathrm{D}$. Immediately following testing, the subjects were examined with a slit-lamp (biomicroscope) to verify that there were no deposits on either their contact lenses or their corneal oedema.

Two emmetropes (cycloplegic refraction between $0.00 \mathrm{D}$ and $+0.50 \mathrm{D}$ ) were tested for standard contrast and reversed contrast visual acuity while wearing plano trial lenses and
$+0.5 \mathrm{D},+1.25 \mathrm{D},+2.00 \mathrm{D}$, and $+2.75 \mathrm{D}$ dioptric defocus. Before testing, subjects spent 30 minutes adapting to the dioptric defocus (as did myopes when tested with uncorrected vision). Testing began immediately thereafter. This period of time was sufficient to adapt to the optical defocus (Rosenfield et al., 2004).

Each subject was tested for monocular (with dominant eye) visual acuity with reversed and standard contrast stimuli. The Weber contrast for reversed and standard contrast optotypes was 35.7 and -0.97 , respectively. The Michelson contrast for both types of contrast optotype was -0.95 . Luminance of bright and dark background was $112 \mathrm{~cd} / \mathrm{m}^{2}$ and $3 \mathrm{~cd} / \mathrm{m}^{2}$, respectively. Both stimulus and background luminance were measured with a Minolta CS-100 chromameter.

The Freiburg Visual Acuity and Contrast Test (FrACT) software was used to test monocular visual acuity (Bach, 2007). The test stimulus was a Landolt $C$ optotype. During testing, it was oriented at random in one of the four orthogonal directions. Stimuli were presented using an adaptive staircase procedure, in which stimulus size was decreased with log steps when a subject submitted a correct answer, and increased when a subject submitted an incorrect answer. During testing, the subject was seated $4.5 \mathrm{~m}$ from a 19" CRT monitor. The subject was asked to indicate the orientation of each stimulus by typing on the computer keyboard. After familiarising herself with the task, the subject underwent several trial measurements, and then testing was started. At least seven measurements took place for each stimulus. Visual acuity measurements were taken for both contrast polarities (standard and reversed) in a random order to avoid any learning effects. Acuity values were expressed in $\log$ MAR units (logarithm of minimum angle of resolution). Smaller $\log$ MAR values represented better visual acuity.

Measurements took place in photopic conditions, for which an illuminance in the eye plane was $~ 80$ lx (illuminance meter T-10, Konica Minolta), regardless of whether the subject was viewing standard or reversed contrast optotypes.

All subjects were students in the Department of Optometry and Vision Science at the University of Latvia. No subject had any known ocular disease, and all myopes had a practice of wearing eyeglasses or contact lenses in everyday life. All participants gave their informed consent. Ethical approval was given by the Ethical Committee of the Institute of Experimental and Clinical Medicine, University of Latvia.

\section{RESULTS}

Figure 1 shows the visual acuity values for emmetropes, while viewing both standard and reversed contrast optotypes, and a Bland-Altman plot (Bland and Altman, 1986) of these data. There was no statistically significant difference between the standard and reversed contrast visual acuity results ( $p=0.17$; paired t-test; two-tailed). 


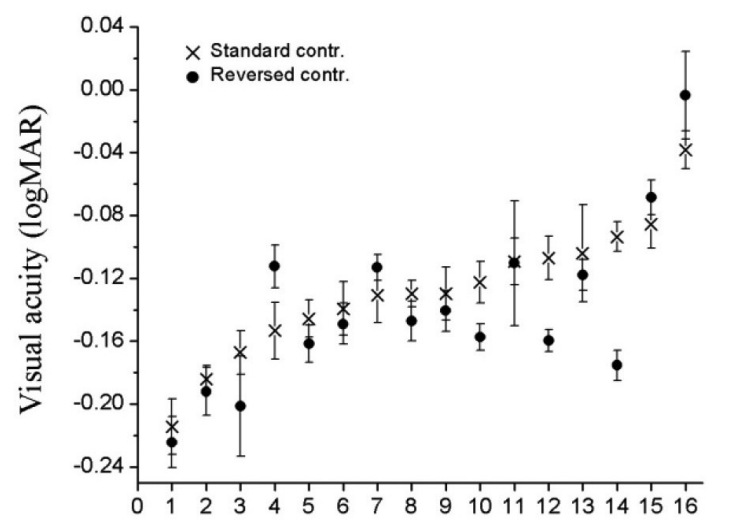

A

Subjects

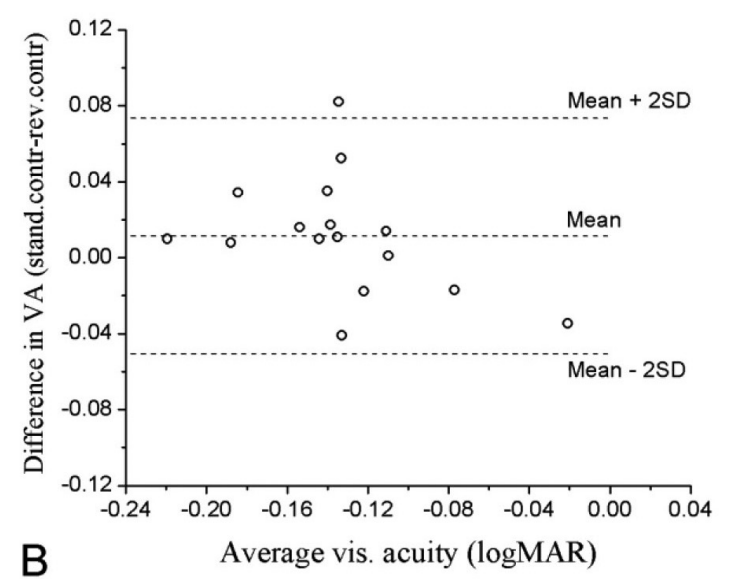

Fig. 1. Visual acuity for emmetropes while viewing both standard and reversed contrast optotypes (A). Standard error is shown for each data point. Bland-Altman plot showing the difference between the visual acuity values of emmetropes while viewing standard or reversed contrast optotypes (B).

Correlation between standard and reversed visual acuity measurements for uncorrected myopes is shown in Figure 2. Visual acuity was significantly better while viewing reversed contrast optotypes, rather than standard contrast optotypes $(p<0.001$; paired t-test; two-tailed). The average difference between the two contrast visual acuity values was $0.15 \pm 0.02 \log$ MAR units. There was a strong correlation between standard and reversed contrast visual acuity values $(\mathrm{R}=0.97)$. The slope coefficient $a$ of a regression line did not significantly differ from 1 .

Also, the average visual acuity values of the two emmetropes (subjects 2 and 10 in Fig. 1A), measured at $+0.5 \mathrm{D}$, $+1.25 \mathrm{D},+2.00 \mathrm{D}$, and +2.75 D dioptric defocus, are shown in Fig. 2. The visual acuity values while viewing both standard and reversed contrast optotypes decreased with increasing optical defocus. The visual acuity results of the emmetropes showed a similar tendency as in the myope data - visual acuity under conditions of optical defocus was better while viewing reversed contrast stimuli, rather than standard contrast stimuli, and the difference between both types of contrast visual acuity values did not systematically increase with increasing optical defocus.

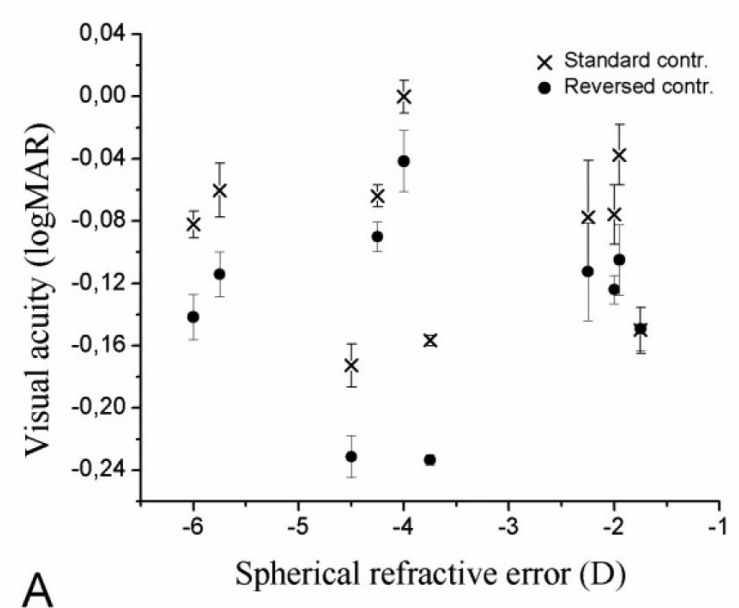

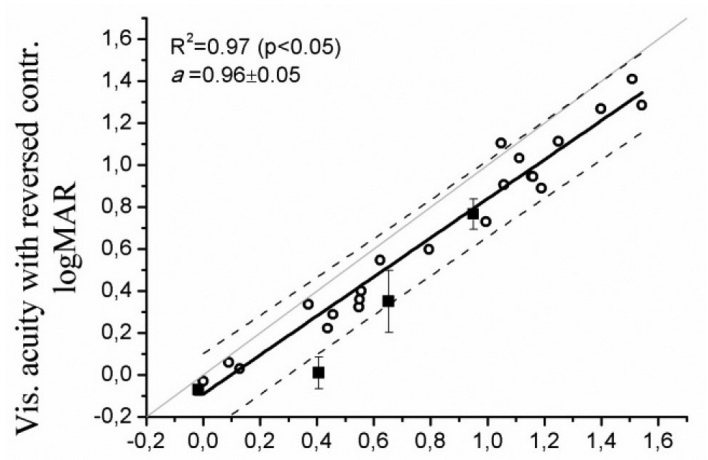

Vis. acuity with standard contr. (logMAR)

Fig. 2. The linear correlation between the standard and reversed contrast visual acuity values for myopes with uncorrected vision (open symbols). The solid black line represents the regression line, and the grey line represents perfect agreement. The dashed lines indicate the $95 \%$ prediction bands. The values of the determination coefficient $R^{2}$ and the slope coefficient $a$ of a regression line are shown. Solid squares show the average visual acuity values of the 2 emmetropes at $+0.5 \mathrm{D}$ (the lowest square), +1.25 $\mathrm{D},+2.00 \mathrm{D}$ and $+2.75 \mathrm{D}$ defocus. Standard error is shown for each of these points.

The standard and reversed contrast visual acuity values for myopes, while wearing spectacles, are shown in Fig. 3.

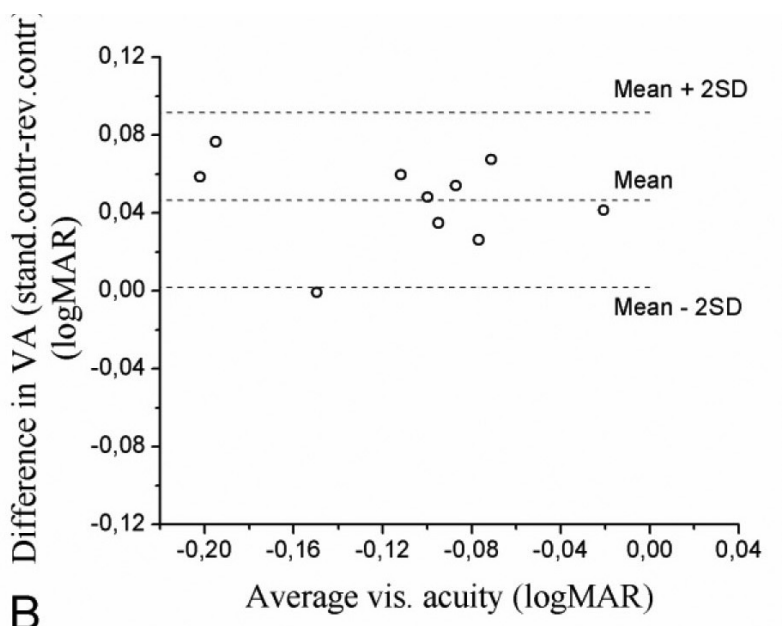

Fig. 3. Standard and reversed contrast visual acuity values as a function of refractive error for myopes with spectacle correction (A). Standard error is shown for each data point. A Bland-Altman plot showing the difference between the standard and reversed contrast visual acuity measurements for myopes with spectacle correction (B). 

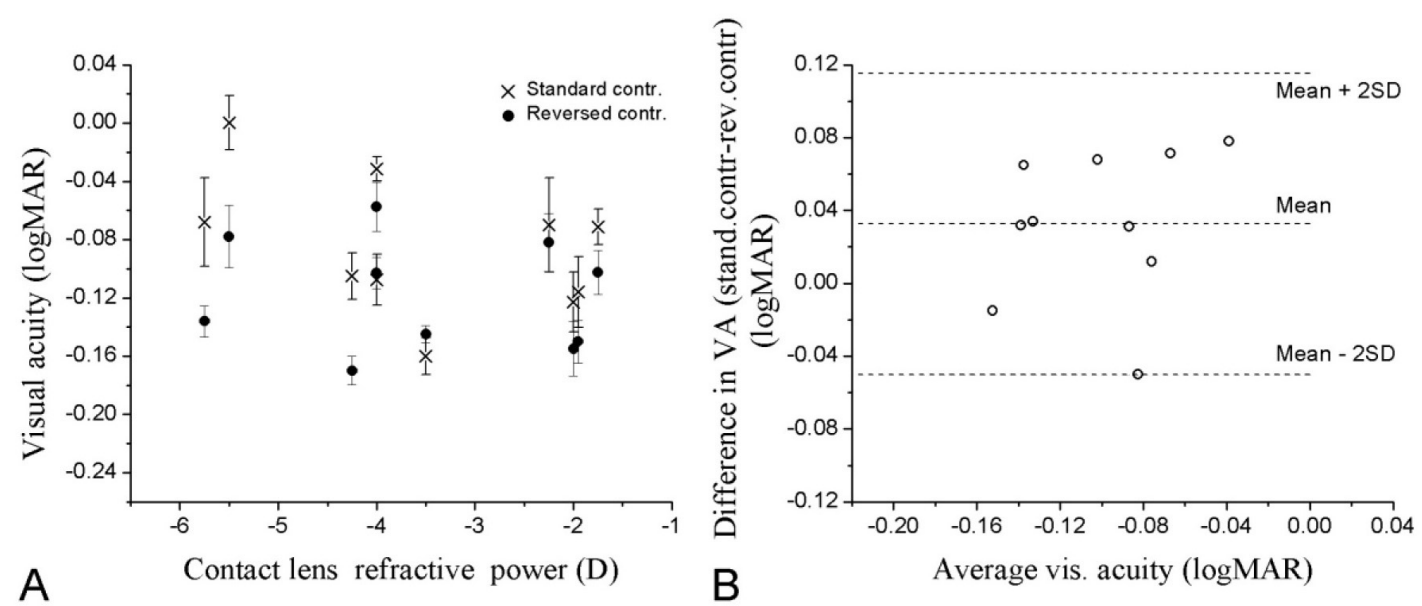

Fig. 4. Standard and reversed contrast visual acuity values for myopes with contact lens correction as a function of the refractive power of the contact lenses (A). Standard error is shown for each data point. A Bland-Altman plot shows the difference between the standard and reversed contrast visual acuity measurements for myopes with contact lens correction (B).

Better visual acuity was observed with reversed contrast stimuli. The average difference between the standard and reversed contrast visual acuity values was $0.05 \pm 0.01$ $(\log M A R)$, which represented a statistically significant difference ( $p<0.001$; paired t-test; two- tailed).

The standard and reversed contrast visual acuity values for myopes with contact lens correction are shown in Figure 4. The difference between both contrast visual acuity values was $0.03 \pm 0.01(\log M A R)$; this was a statistically significant difference ( $p<0.05$; paired t-test; two- tailed). The difference was similar to that obtained with spectacle correction $(p>0.05)$.

\section{DISCUSSION}

As expected, the results showed that myopes with uncorrected vision, and, therefore, defocused (blurry) vision, exhibited a significantly larger difference in visual acuity values between the standard and reversed contrast Landolt optotypes than in the case of myopes with corrected vision ( $p<0.05$; paired t-test; two-tailed). The average difference between both contrast visual acuity values for uncorrected myopes did not change significantly as the level of optical defocus increased - the slope coefficient $a$ of a regression line did not significantly differ from 1 . This also indicates that even a small level of optical defocus $(+0.25 \mathrm{D})$ can elicit better visual acuity while viewing reversed rather than standard contrast optotypes.

To verify that the same tendency occur with induced optical defocus, we also tested two emmetropes with blurred vision. The average values for both subjects were inside the $95 \%$ confidence bands of the myopes results, except for those results obtained at an optical defocus $+1.25 \mathrm{D}$ (Fig. $2)$. We therefore conclude that the results with induced defocus are similar to the myopes values for uncorrected vision.

Visual acuity of young myopes wearing either eyeglasses or contact lenses was significantly better while viewing re- versed contrast stimuli, rather than opposite contrast polarity stimuli. On average this difference was $\sim 0.04 \log$ MAR units. While being statistically significant, such a small difference is not clinically significant. For example, the repeatability of an ETDRS chart, the format for which is regarded as the main international standard for visual acuity tests (Williams et al., 2008), is approximately one row or $\sim 0.10$ logMAR units (Raasch et al., 1998). Also, we did not record the approximate iris colour of the subjects' eyes. The straylight in eyes with less pigmentation (blue eyes) is larger than in well-pigmented eyes (brown eyes) (Franssen et al., 2008). We only tested 10 myopes with corrected vision, and if most of the subjects in such a small group possess less pigmented eyes (producing increased retinal straylight), this could result in better visual acuity values while viewing reversed rather than standard contrast optotypes. Another aspect which must be taken into account is that we approximated the full optical correction of the myopes, while neglecting cycloplegia. Our end-point criterion to determine the final correction was based on one of the standard laws in optometry: "maximum plus lens or minimum minus lens power for best visual acuity" (Grosvenor, 2007). The accuracy of the final correction is limited to $+/-0.25 \mathrm{D}$ (the optical step size of trial lenses), but even at this defocus, one can achieve better visual acuity with reversed rather than standard contrast stimuli.

One of our aims was to determine whether the difference between the reversed and the standard contrast visual acuity values was the same for contact lens and eyeglass wearers. The differences in visual acuity values were not statistically significant, regardless of whether the subject was wearing eyeglasses or contact lenses. This confirms the results of other studies (Cervińo et al., 2008; van der Meulen et al., 2010) showing that soft contact lenses and clean eyeglass lenses increase retinal straylight insignificantly. We measured visual acuity rather than straylight, but we can conclude that if optical correction increases retinal straylight, this will have some impact on both the reversed and standard contrast visual acuity values, and that this effect is the same for both eyeglass and contact lens wearers. 
Our results showed that that myopes can have slightly better visual acuity while viewing reversed rather than standard contrast optotypes, especially with their habitual optical correction (eyeglasses or contact lenses). The type of correction - eyeglasses or contact lenses - produces similar visual acuity values for both contrast polarities.

\section{ACKNOWLEDGEMENT}

This work was supported by ESF project No. 2013/0021/ 1DP/1.1.1.2.0/13/APIA/VIAA/001.

\section{REFERENCES}

Allen, R. J., Saleh, G. M., Litwin, A. S., Sciscio, A., Beckingsale, A. B., Fitzke, F. W. (2008). Glare and halo with refractive correction. Clin. Exp. Optom., 91 (2), 156-160.

Bach, M. (2007). The Freiburg Visual Acuity Test-variability unchanged by post-hoc re-analysis. Graefes Arch. Clin. Exp. Ophthalmol., 245 (7), 965-971

Bland, J. M., Altman, D. G. (1986). Statistical methods for assessing agreement between two methods of clinical measurement. Lancet, 1 (8476), 307-310.

Cervińo, A., Gonzalez-Meijome, J. M., Linhares, J. M., Hosking, S. L., Montes-Mico, R. (2008). Effect of sport-tinted contact lenses for contrast enhancement on retinal straylight measurements. Ophthalmic. Physiol. Opt., 28 (2), 151-156.

Elliott, D. B., Mitchell, S., Whitaker, D. (1991). Factors affecting light scatter in contact lens wearers. Optom. Vis. Sci., 68 (8), 629-633.

Franssen, L., Coppens, J. E., van den Berg, T. J. T. P. (2008). Grading of iris color with an extended photographic reference set. J. Optom., 1 (1), 36-40.

Grosvenor, T. (2007). Primary Care Optometry. Butterworth-Heinemann, Elsevier, Hong Kong. 510 pp.

Haegerstrom-Portnoy, G., Schneck, M. E., Lott, L. A., Brabyn, J. A. (2000). The relation between visual acuity and other spatial vision measures. Optom. Vis. Sci., 77 (12), 653-662.

Received 22 April 2016

Accepted in the final form 4 August 2016
Marcos, S., Sawides, L., Gambra, E., Dorronsoro, C. (2008). Influence of adaptive-optics ocular aberration correction on visual acuity at different luminances and contrast polarities. J. Vis., 8 (13), 1-12.

van der Meulen, I. J., Engelbrecht, L. A., van Vliet, J. M. (2010). Straylight measurements in contact lens wear. Cornea, 29 (5), 516-522.

Miyajima, H. (1992). Studies on contrast visual acuities in normal, cataractous and pseudophakic eyes. Keio J. Med., 41 (4), 212-220.

Piepenbrock, C., Mayr, S., Mund, I., Buchner, A. (2013). Positive display polarity is advantageous for both younger and older adults. Ergonomics, 56 (7), 1116-11124

Raasch, T. W., Bailey, I. L., Bullimore, M. A. (1998). Repeatability of visual acuity measurement. Optom. Vis. Sci., 75 (5), 342-348.

Rosenfield, M., Hong, S. E., George, S. (2004). Blur Adaptation in Myopes. Optom. Vis. Sci., 81 (9), 657-662.

Rozema, J. J., Van den Berg, T. J., Tassignon, M. J. (2010). Retinal straylight as a function of age and ocular biometry in healthy eyes. Invest. Ophthalmol. Vis. Sci., 51 (5), 2795-2799.

Rubin, G. S., Legge, G. E. (1989). Psychophysics of reading. VI. The role of contrast in low vision. Vision Res., 29 (1), 79-91.

Stoimenova, B. D. (2007). The effect of myopia on contrast thresholds. Invest. Ophthalmol. Vis. Sci., 48 (5), 2371-2374.

Westheimer, G. (2003).Visual acuity with reversed-contrast charts: I. Theoretical and psychophysical investigations. Optom. Vis. Sci., 80 (11), $745-748$.

Westheimer, G., Chu, P., Huang, W., Tran, T., Dister, R. (2003). Visual acuity with reversed-contrast charts: II. Clinical investigation. Optom. Vis. Sci., 80 (11), 749-752.

Whitaker, D., Elliott, D. B. (1992). Simulating age-related optical changes in the human eye. Doc. Ophthalmol., 82 (4), 307-316.

Williams, M. A., Moutray, T. N., Jackson, A. J. (2008). Uniformity of visual acuity measures in published studies. Invest. Ophthalmol. Vis. Sci., 49 (10), 4321-4327.

de Wit, G. C., Coppens, J. E. (2003). Stray light of spectacle lenses compared with stray light in the eye. Optom. Vis. Sci., 80 (5), 395-400.

\section{REDZES ASUMS MIOPIJAS GADĪJUMĀ AR STANDARTA UN REVERSA KONTRASTA STIMULIEM}

Darba mērḳis bija novērtēt, kā miopu (dalībnieku ar tuvredzību) redzes asumu, kas noteikts ar standarta un reversa kontrasta stimuliem, ietekmē optiskais apmiglojums un redzes korekcijas veids — brilles vai kontaktlēcas. 23 miopiem (18 līdz 23 gadus veci) tika noteikts nekoriǵétais redzes asums ar standarta un reversa kontrasta optotipiem. Standarta kontrasta stimulu veidoja tumšs optotips, kas tika rādīts uz gaiša fona. Reversa kontrasta stimula gadījumā tika rādīts gaišs optotips uz tumša fona. Desmit dalībniekiem papildus tika veikti redzes asuma mērījumi ar brillēm un kontaktlēcām. Nekoriǵētiem miopiem redzes asums bija labāks ar reversa nekā standarta kontrasta optotipiem. Līdzīga tendence tika novērota arī mērījumos ar brillēm un kontaktlēcām — redzes asums bija nedaudz labāks ar reversa nekā standarta kontrasta stimuliem. Miopu redzes asuma pasliktinājums ar standarta kontrasta optotipiem attiecībā pret reversa kontrasta stimuliem lielā mērā ir skaidrojams ar zemāko kārtu aberāciju (optiskā defokusa) ietekmi uz redzes kvalitāti. 